\title{
Bezpieczeństwo jako podstawowy element realizacji utopii edukacyjnych XIX i XX wieku
}

\author{
Ideały sa jak gwiazdy. Jeśli nawet nie możemy ich \\ osiagnać, to należy się wedlug nich orientować.
}

George Bernard Shaw

KEY WORDS

utopia, education, sociology of education, philosophy of education

\begin{abstract}
Futyma Sławomir, Bezpieczeństwo jako podstawowy element realizacji utopii edukacyjnych XIX i XX wieku [Safety as the Basic Element of Realization of 19th and 20th Century Educational Utopias]. Kultura Społeczeństwo - Edukacja nr 2(10) 2016, Poznań 2016, pp. 125-136, Adam Mickiewicz University Press. ISSN 2300-0422. DOI 10.14746/ kse.2016.10.10.

This reflection is associated with unquestionable power of utopia in education. Education has always been associated with the implementation of social utopia. The intensity of this activity can be observed especially in the nineteenth and twentieth centuries. With utopia, education systems may take into account future scenarios, risk, and to disseminate the truth that knowledge and early solution to the problems is a prerequisite for social security.
\end{abstract}

\section{Wstęp}

Niniejsza refleksja związana jest $\mathrm{z}$ niekwestionowaną mocą utopii $\mathrm{w}$ edukacji. Edukacja stanowiła, bez względu na okres i miejsce, mniej lub bardziej skuteczne narzędzie realizacji „jakiegos” świata. Natężenie tego działania daje się zauważyć zwłaszcza w XIX i XX wieku. Poniższa refleksja dotyczy zjawiska edukacji, jej instytucjonalnego wymiaru, wpisanego w politykę państwa. Przez tryby tego, co potocznie nazywane jest edukacją, przechodzi obecnie $100 \%$ obywateli. Niektórzy utożsamiają edukację ze szkołą lub, jak napisał profesor Piotr Jaroszyński, 
w dużym stopniu redukując i upraszczając to zjawisko, że edukacji jest to: „systematyczna i rozłożona w czasie forma przekazu umiejętności i wiedzy z pokolenia na pokolenie [która to - S.F.] obecna jest w świecie ludzi” (Jaroszyński, 2005: 13).

A jeżeli jest to miejsce, czyli szkoła, oraz czas, to wielu młodych ludzi traktuje to jako czas odsiadki ciężkiego wyroku, no bo przecież 6 lat szkoły podstawowej, 3 lata gimnazjum, 3 lata liceum, bądź 4 lata technikum, studia 3 plus 2 lata, to już 5 lat, w sumie daje nam to 17-18 lat. Taki specyficzny „wyrok”. 17 lat więzienia, wymiar sprawiedliwości nakłada na przestępców za zabójstwa i zamachy terrorystyczne, za przestępstwa ze szczególnym okrucieństwem.

Niestety, badania postaw współczesnych uczniów oraz studentów dają uzasadnioną podstawę do sformułowania wniosku, że duża część młodych ludzi traktuje ten okres i miejsce jak odsiadkę bolesnego wyroku bądź, w wersji lżejszej, jako zło konieczne.

Czy funkcjonowanie społecznych utopii ma na to jakiś wpływ? Czy jeżeli ma wpływ, to w takim razie, czy utopie mogą służyć jako narzędzie wychowawcze? I w końcu pytanie: jaki element spajałby myślenie utopijne w/o edukacji i czyniłby zeń skuteczne narzędzie oddziaływania społecznego, tworząc z ludzi wspólnotę, społeczeństwo, naród czy też państwo bądź superpaństwo? I czy tą płaszczyzną spajającą jest tworzenie poczucie „bezpieczeństwa” bez względu na realizowane idee, temu służące?

\section{Świat, instytucje i utopie}

Chyba najbardziej brzemienną w skutki zmianą, jaka nastąpiła w historii ludzkości, była ta związana $\mathrm{z}$ odkryciem, że treści $\mathrm{w}$ procesie poznawania, odbierane przez człowieka, tworzące obszar wiedzy można przekształcać zgodnie ze swoim własnym upodobaniem, a świat w taki sposób przekształcony można „zinstytucjonalizować”. „Instytucjonalizację”, o której myślę, należy traktować jako produkt uzurpacji, określonych grup społecznych lub jednostek, wynikających z ich własnego interesu w orzekaniu o rozmaitych przestrzeniach życia, na przykład estetycznej, gdzie orzekanie będzie prowadziło do kształtowania tego, co „ładne” albo "brzydkie” w kreowaniu otoczenia; orzekanie w przestrzeni etycznej, będzie z kolei sprowadzało się do wskazywania tego, co „dobre” albo, co „złe” w przekonaniu orzekających.

Nawiążę w tym momencie tylko do jednego przykładu obecnego w przestrzeni naszego kręgu kulturowego, służącego do modyfikowania postaw i poglądów. Najczęściej eksploatowanym motywem, modyfikującym, przekonania, światopoglądy, stała się alegoria jaskini platońskiej. Gdzie za starożytnymi filozo- 
fami na czele z Platonem, zmysły rozumiane jako „ciało” stały się synonimem niedoskonałości lub wręcz ułomności. Ułomność ta to niewidoczny łańcuch trzymający nas w materialnym świecie pozoru, który nie jest światem rzeczywistym. To, co składa się na zmysłowy świat, zmienia się i w efekcie ginie. Ta chwilowość, przelotność, to cechy niedoskonałości materialnego świata, który nas otacza. Natomiast cechami świata doskonałego, świata trwałego, stały się: niezmienność oraz wieczność niedająca się ograniczyć czasem i przestrzenią i niedająca się wyobrazić. Ta powszechnie stosowana alegoria wygenerowała przeciwne stanowisko, które to do dzisiaj zdobywa sobie wielu zwolenników, a okres rozkwitu możemy dostrzec na przełomie XIX i XX wieku. Jest to pogląd rezygnujący $\mathrm{z}$ tego, co stałe, niezmienne i doskonałe, a podkreślający potrzebę chwytania przelotności, a tym samym lokowania człowieka w tym, co tu i teraz, nietrwałe i zmienne.

Zachwyt przelotnością i osadzenie $\mathrm{w}$ dotykalnym świecie określamy jako modernizację życia. Modernizacja ta to szczególny zwrot w patrzeniu na człowieka i jego edukacyjne otoczenie. Efektem tego okresu staje się uzależnienie jednostki od zinstytucjonalizowanego społeczeństwa. Możemy mówić o postępującym zwrocie socjocentrycznym w jego rozmaitych odcieniach od socjalizmów „miękkich” do jego totalitarnych „barw”, wszystko w celu uszczęśliwienia rodzaju ludzkiego (Kiereś, 2005: 222). Taki cel, jakim jest rozmaicie rozumiane szczęście, przyświecał różnej maści socjalizmom i liberalizmom. Misja „uszczęśliwiania" wybranych towarzyszy historii komunizmu, faszyzmu i nazizmu.

Ta potrzeba uszczęśliwiania innych wyłania się, między innymi, z idei takich myślicieli jak A. Comte, G.W.E Hegel czy też K. Marks. Gdyż, jak to podkreślił, profesor H. Kiereś, w poglądach wielu myślicieli tego okresu:

dzieje ludzkości są historią samowyzwalania się człowieka. Rozmaite historiozofie głoszą, że historia jest areną realizacji koniecznych (nieuniknionych) praw ontologicznych i antropologicznych, głównie społecznych. Na człowieku spoczywa obowiązek rozpoznania tych praw, a następnie ich bezwzględnego wdrożenia w życie społeczne. (Kiereś, 2005: 222)

Zmiany, jakie następowały w XIX i XX wieku, dotyczące sposobu myślenia o świecie, dotyczyły w głównej mierze doboru strategii wraz z narzędziami, aby działać w imię konstruowania „świata życia”. Działania te przybierały niejednokrotnie dramatyczny bieg. Dramatyzm ten, w literaturze tak pięknej, jak i naukowej najczęściej bywa dostrzegany w ograniczaniu związku człowieka z jego naturalnym biologicznym rytmem (Naisbitt, Naisbitt, Philips, 2003: 44). Bo przecież jeszcze nie tak dawno większość ludzi:

budziła się o wschodzie słońca i kładła spać o zachodzie, jadła posiłki przygotowane $\mathrm{w}$ domu, pracowała nieopodal miejsca zamieszkania. Ludzie mówili o przelotnych chwi- 
lach, trwałych wspomnieniach i upominali dzieci, że „co nagle, to po diable”. Opowieści zaczynano od słów: „Dawno, dawno temu”, i rzeczywiście coś to znaczyło. Dni podporządkowane były bardziej obecności światła dziennego, niż godzinom, a lata bardziej porom roku niż kartkom w kalendarzu. (Naisbitt, Naisbitt, Philips, 2003: 44)

Tak też zapach, widzenie, słyszenie czy też czucie bliskości i ciepła współobecnych, albo pustka wynikająca $\mathrm{z}$ ich braku, tworzyły obrazy otaczającej ludzi rzeczywistości. Dowodem na prawidłowy rozwój człowieka było sensowne przekazywanie odebranych, zmagazynowanych i przetworzonych informacji, które to wprost wpływały na rozwój, a tym samym na wzmacnianie działania jednostki. Zgodzimy się chyba wszyscy z poglądem, że porządek ten został zburzony, a utopia stanęła w opozycji do człowieka traktowanego jako część natury. Gdzie, zmodernizowany świat, przeciwstawił się biologicznej naturze człowieka.

Końcem euforii wokół modernizacji świata okazały się próby realizacji czegoś, co nie mogło odnieść sukcesu. I tak pod koniec XX wieku liczni naukowcy, publicyści i politycy powiadomili o załamaniu się dotychczasowych pomysłów intelektualnych i obwieścili „koniec historii” oraz nadejście nowej, postmodernistycznej idei głoszącej „wyzwolenie wolności”. Wraz z wyzwoleniem okrzyknięto potrzebę innej, nowej globalnej demokracji, usprawiedliwiając jednocześnie ewentualne skutki osiągnięcia tego „nowego starego” porządku (por. Kiereś, 2000).

\section{Utopie i co dalej?}

Socjalizmy, liberalizmy, komunizmy, faszyzmy czy też nazizmy - każdy z tych systemów miał swoją charakterystyczną pedagogię, czyli paradygmat, model edukacyjny mogący przybierać postać doktryny, ideologii edukacyjnej bądź ukrytego programu wychowawczego, obejmującego całość społeczeństwa, a więc w swojej istocie totalitarnego. Częścią takiego programu wychowawczego zawsze było wyobrażenie doskonałości, rozumiane jako warunek sine qua non i ostateczny cel, a tym samym narzędzie, oraz strategia urzeczywistnienia pożądanego stanu rzeczy. Utopia zatem definiuje cel, określa działania, jest narzędziem tworzącym klimat atrakcyjności, i w efekcie może służyć usprawiedliwieniu w sytuacji porażki w realizacji zamierzonego celu (por. Kiereś, 2000).

W analizie kategorii pojęciowej „utopia”, dokonanej przez profesora Jerzego Szackiego, odnajdujemy trzy istotne płaszczyzny rozumienia pojęcia „utopia”. Rozumienia te wpisują się w przestrzeń działań edukacyjnych, i są to: utopie rozumiane jako mrzonki; utopie rozumiane jako ideały ukierunkowujące działania ludzkie w stronę poprawienia zastanego stanu rzeczy oraz utopie jako hipotezy wskazujące na istnienie konkurencyjnych rozwiązań, pojawiających się w ramach myślowego eksperymentu (Szacki, 1980: 14-33). 
Jeżeli chodzi o funkcjonowanie kategorii pojęciowej „utopia” w języku potocznym, to, jak napisał, profesor Jerzy Szacki:

słowo utopia oznacza najczęściej mrzonkę, chimerę, wytwór nie liczącej się z faktami fantazji, projekt, którego urzeczywistnienie nie jest możliwe. Być utopistą to tyle, co być człowiekiem skrajnie niepraktycznym, nie liczyć się zupełnie z rzeczywistością i tzw. realnymi możliwościami. (Szacki, 1980: 14)

Zaś jeżeli chodzi o utopie w rozumieniu ideałów ukierunkowujących działania ludzkie, aby poprawić zastany stany rzeczy, profesor Szacki podkreśla:

Słowem utopia określa się też często wszelkie wizje lepszego społeczeństwa niezależnie od tego, jakie były czy też są szanse na ich realizację. Utopiami w tym znaczeniu będą więc wszelkie systemy poglądów ugruntowane na sprzeciwie wobec aktualnie istniejących stosunków i przeciwstawieniu im propozycji stosunków innych, bardziej odpowiadających istotnym potrzebom ludzkim. (Szacki, 1980: 21)

A sięgając nieco w przeszłość, chociaż nie do początku idei, bo nie jest to czas na tego typu refleksję, tylko przypomnę, że systemy myślowe, określane mianem utopijnych z XIX i XX wieku, korzystały z dorobku takich myślicieli jak Charles Fourier, Francis Bacon, William Morris. Czy to pitagorejczyków, tkwiących u źródła utopii wegetariańskiej, czy to wolnomularzy opowiadających się za istnieniem utopijnego świata, braterstwa i uniwersalizmu braci i sióstr pochodzący od jednego ojca i matki, których łączą więzy krwi, jednoczyła idea lepszego świat, świata tu i teraz.

\section{Edukacja i utopia}

XIX i XX wiek na dobre włączyły konstrukcje intelektualne, jakimi są utopie, w przestrzeń społeczną. W tym to czasie objawiły się one jako strategie i doktryny polityczne jednocześnie. Tak też utopie stały się swoistą inżynierią społeczną, ucieleśniającą się w postaci rozmaitych ideologii. Kolejnym etapem było zastosowanie tychże w przestrzeni edukacji społecznej, która to łączy elementy praktyki i teorii. Działania te miały służyć produkcji nowego człowieka, charakteryzującego się pożądanymi parametrami, na poziomie fundamentalnych procesów myślowych i zachowań społecznych. Myślano o człowieku świadomym i zdolnym do reagowania na bodźce zewnętrzne.

Czym zatem jest edukacja? Definicję dostarcza nam tutaj profesor Zbigniew Kwieciński, polski prekursor dyscypliny określonej mianem socjologii edukacji. W swojej pracy zatytułowanej Dziesięciościan edukacji definiuje on edukację w następujący sposób: 
Edukacja to (...) ogół wpływów na jednostki i grupy ludzkie, wpływów sprzyjających takiemu ich rozwojowi i wykorzystywaniu posiadanych możliwości, aby w maksymalnym stopniu stały się świadomymi i twórczymi członkami wspólnoty społecznej, narodowej, kulturowej i globalnej oraz by stały się zdolne do aktywnej samorealizacji, niepowtarzalnej i trwałej tożsamości i odrębności, były zdolne do rozwijania własnego JA poprzez podejmowanie 'zadań ponadosobistych, poprzez utrzymanie ciągłości własnego JA w toku spełnienia „zadań dalekich”. (Kwieciński 1998)

Tak też wspominane powyżej „mechanizmy wpływów”, tworzące z człowieka twórczego członka wspólnoty społecznej, narodowej, kulturowej i globalnej, stają się elementem spajającym utopie $\mathrm{z}$ przestrzenią edukacyjną. Edukacja $\mathrm{w}$ tym ujęciu jest nośnikiem kultury, która realizuje się w ramach określonych cywilizacji.

Relację współzależności utopi i edukacji zauważył także Andrzej Dróżdż z Uniwersytetu Pedagogicznego w Krakowie, gdy napisał:

Istnieje bowiem ścisła prawidłowość: gdy w społeczeństwie zdobywają popularność utopie ładu społecznego, uaktywniają się równocześnie pedagogiki normatywne, a gdy popularyzują się utopie eudajmonistyczne, wówczas słabną pedagogiki normatywne (formalne), a uaktywniają się pedagogiki nieformalne. W dzisiejszej kulturze zachodniej ma miejsce to drugie zjawisko, tzn. uaktywniania się pedagogik nieformalnych i coraz większej skuteczności wychowywania bodźcowego przeważnie z niesterowalnych źródeł, rządzonych prawami wolnego rynku, zdominowanych przez telewizję, Internet i reklamy towarów konsumpcyjnych. (Dróżdż, 2000: 6-7)

W historii naszego kraju możemy odnaleźć próby praktycznej realizacji edukacyjnych utopii. Takim przykładem było Miasteczko Dziecięce w Podgrodziu. Stalinowska utopia, w której miały rządzić dzieci. To jedyne w swoim rodzaju zjawisko opisał w artykule Robert Jurszo, dziennikarz, publicysta, historyk idei. Jak napisał autor:

„Tu, w Miasteczku Dziecięcym w Podgrodziu nad Zalewem Szczecińskim, próbowano uformować nowego, socjalistycznego człowieka”. (...) „to maleńkie Podgrodzie tym jest dziwne, iż jest to pierwsze i dziś jedyne w Polsce miasteczko, które w całej pełni można nazwać dziecięcym. Poza niezbędną grupką opiekunów, lekarzy, pedagogów, mieszkają tam wyłącznie dzieci, które same się obsługują, same się rządzą i same o sobie stanowią" - rozpisywali się autorzy (...) książeczki „Miasteczko Dziecięce w Podgrodziu” (...). I rzeczywiście, porządku na ulicach pilnowali ubrani w milicyjne mundurki malcy. Pomiędzy domkami biegali roznoszący pocztę mali listonosze. Poza tym, funkcjonowały również służby: morska, zdrowia oraz kolejowa. Ta ostatnia obsługiwała największą atrakcję Podgrodzia: kolejkę wąskotorową. Jej linia okalała Podgrodzie i biegła przez bardzo zróżnicowany teren - miasteczko, pas nadbrzeżny, las i tereny podmokłe. Był też dworzec główny z poczekalnią, kasą biletową i peronem. (Jurszo, 2016) 


\section{Edukacja, utopia i bezpieczeństwo czyli bezpieczeństwo emanacja utopii}

W dotychczasowej historii ludzkości, zwłaszcza w XIX i XX wieku, utopie jako systemy myślowe skierowane na porządkowanie życia według sobie wiadomych kryteriów projektowały świat „tu i teraz”, świat pożądany i możliwy do zaistnienia, choć chwilowo nieobecny. Twórcy tychże pomysłów wskazywali, jakie elementy należy z życia wyeliminować, aby wskazany ideał osiągnąć. Te utopijne projekty edukacyjne usiłowały ogarnąć człowieka wraz $\mathrm{z}$ jego przestrzenią życiową i aktywnością, wymuszając określony sposób życia, rozpoczynając za każdym razem realizację swojego projektu od eliminowania niedogodności życiowych wynikających z zaistniałej sytuacji historycznej.

Istnieje wiele elementów spajających logiki utopijne i przestrzeń edukacyjną. Jeden $\mathrm{z}$ tychże elementów został bardzo mocno podkreślony przez profesora Jerzego Szackiego. A mianowicie, jak napisał profesor Szacki: „Utopista nie godzi

Tabela 1. Typy utopii

\begin{tabular}{|l|l|l|l|l|}
\hline \multicolumn{1}{|c|}{ Typy utopii } & $\begin{array}{l}\text { Typy racjonalno- } \\
\text { ści edukacyjnej }\end{array}$ & $\begin{array}{c}\text { Typy orientacji } \\
\text { edukacyjnej }\end{array}$ & \multicolumn{2}{|c|}{$\begin{array}{c}\text { Bezpieczeństwo jako stan możliwego, } \\
\text { akceptowalnego ryzyka } \\
\text { (cel utopii - trwanie pomiędzy) }\end{array}$} \\
\hline Laboratoryjna & Naukowa & $\begin{array}{l}\text { Orientacja na po- } \\
\text { szukiwanie wiedzy }\end{array}$ & Kompetencyjność & $\begin{array}{l}\text { Tworzenie naukowego } \\
\text { getta }\end{array}$ \\
\hline Ekologiczna & $\begin{array}{l}\text { Antytechniczna } \\
\text { naturalistyczna }\end{array}$ & $\begin{array}{l}\text { Orientacja na tro- } \\
\text { pienie i unikanie } \\
\text { możliwych manipu- } \\
\text { lacji }\end{array}$ & $\begin{array}{l}\text { Umiejętność obserwacji } \\
\text { (wyjaśnianie możliwego } \\
\text { do wyjaśnienia) }\end{array}$ & $\begin{array}{l}\text { Tworzenie spiskowych } \\
\text { teorii dziejów (wyjaśnia- } \\
\text { nie w przypadku braku ra- } \\
\text { cjonalnych argumentów) }\end{array}$ \\
\hline Wegetariańska & Hedonistyczna & $\begin{array}{l}\text { Orientacja na uni- } \\
\text { kanie cierpienia i za- } \\
\text { spokajanie potrzeb }\end{array}$ & $\begin{array}{l}\text { Dzielenie się, akceptacja } \\
\text { różnorodności i odmien- } \\
\text { ności }\end{array}$ & $\begin{array}{l}\text { Likwidacja odruchów } \\
\text { samo regulacyjnych }\end{array}$ \\
\hline Antyrynkowa & Społeczna & $\begin{array}{l}\text { Orientacja na soli- } \\
\text { darność społeczną }\end{array}$ & $\begin{array}{l}\text { Sprawiedliwy podział } \\
\text { obowiązków i dóbr }\end{array}$ & $\begin{array}{l}\text { Antagonizowanie społe- } \\
\text { czeństwa }\end{array}$ \\
\hline Nowego Kościoła & Duchowa & $\begin{array}{l}\text { Orientacja terapeu- } \\
\text { tyczna }\end{array}$ & $\begin{array}{l}\text { Odkrywanie „sił ducho- } \\
\text { wych” i krytycyzm }\end{array}$ & $\begin{array}{l}\text { Tymczasowość i doraź- } \\
\text { ność rozwiązań }\end{array}$ \\
\hline $\begin{array}{l}\text { Nieśmiertelnego } \\
\text { ciała }\end{array}$ & Wirtualna & $\begin{array}{l}\text { Orientacja na har- } \\
\text { monię i przyjem- } \\
\text { ność }\end{array}$ & $\begin{array}{l}\text { Odkrywanie „sieci” jako } \\
\text { nieograniczonej wy- } \\
\text { obraźni ludzkiej }\end{array}$ & $\begin{array}{l}\text { Ucieczka od realnego } \\
\text { świata }\end{array}$ \\
\hline Czystego rozumu & Oświeceniowa & $\begin{array}{l}\text { Orientacja na two- } \\
\text { rzenie świata bez } \\
\text { „bogów” }\end{array}$ & $\begin{array}{l}\text { Odkrywanie rozumu jak } \\
\text { racjonalnego ideału }\end{array}$ & $\begin{array}{l}\text { Relatywizm i zwątpienie } \\
\text { w sens egzystencji }\end{array}$ \\
\hline
\end{tabular}


się na zastany świat, nie zadowala się aktualnie istniejącymi możliwościami: marzy, fantazjuje, antycypuje, eksperymentuje, projektuje" (Szacki, 1980: 33).

Działania antycypujące należy rozumieć wprost jako tworzenie przestrzeni bezpieczeństwa rozumianego jako efekt kształtowania umiejętności, postaw i systemów wartości, sprzyjających budowaniu i ochronie świata w przyszłości. Stan bezpieczeństwa, o którym nie mówi się wprost, będzie uwzględnianiem możliwego, świadomego, akceptowalnego ryzyka poziomu utraty, na przykład części wolności, części własności, części zdrowia itd. Dlatego też edukacja, będąca narzędziem realizacji utopii, stara się za każdym razem upowszechniać prawdę o tym, że poznanie i wcześniejsze rozwiązywanie wyzwań jest warunkiem sine qua non tego, by nie przekształciły się one w zagrożenia, że można je traktować jako szansę, a nie groźbę. Działanie takie staje się edukacją do swoiście rozumianego bezpieczeństwa $\mathrm{w}$ ramach projektowanego świata.

Przyjrzyjmy się utopiom, jakie zwłaszcza na przełomie XIX i XX wieku osiągały swoje kulminacje. W zestawieniu poniższym możemy dostrzec typy utopii, modele racjonalności i orientacji edukacyjnej tychże utopii, oraz bezpieczeństwo rozumiane jako cel realizacji modelu przyszłości poszczególnych utopii. Każdemu ze wskazanych typów utopii edukacyjnych towarzyszy inny sposób realizowania celu, jakim jest utopia tożsama $\mathrm{z}$ poczuciem bezpieczeństwa $\mathrm{w}$ świecie o określonych parametrach.

I mamy tutaj między innymi:

- Utopie: ziemi, pokoju i nauki. Wzorem tutaj jest Antarktyda, chroniona międzynarodowymi paktami o pokoju i współpracy, gdzie to wiedzą naukową się nie handluje, a staje się ona własnością całej ludzkości, gdzie podstawową cechą działania jest współpraca. W ten sposób to Antarktyda stanowi najlepsze laboratorium dla podejmowania badań nad zjawiskami klimatycznymi i atmosferycznymi. Tutaj pamięć o Ziemi od tysięcy lat jest przechowywana w lodzie.

- Utopia ekologiczna, która to przeciwstawi się niekontrolowanemu postępowi technicznemu i tym samym pomoże w odzyskaniu utraconego Edenu dzięki sile, jaka spoczywa w Ludzkości, zdolnej, aby powrócić do stanu doskonałości (por. Bacon, 1955). Te działania są możliwe dzięki nauce rozumianej jako siła i moc do przekształcania świata. Jednocześnie realizacja tejże wydaje się niemożliwa, gdy przyjrzymy się na przykład emisji gazów cieplarnianych do atmosfery, mogących spowodować klimatyczny pożar.

- Utopia wegetariańska, podkreślając odmienność i różnorodność co do jakości i poziomu egzystencji gatunkowej, czy też społecznej, przeciwstawia się wyzyskowi i uprzedmiotowieniu, które prowadzi do wszelkiego rodzaju wyzysku czy też okrucieństwa. Utopia ta „dotyczy jednostek - ich wrażli- 
wości, skłonności do unikania cierpienia i zaspokajania ich potrzeb, aby mogły wieść godne życie” (Mery, 2007: 37).

- Utopia antyrynkowa, bazująca na poczuciu wspólnoty ludzkiej, która to ogranicza wpływ rynku i orientacji na zysk w kreowaniu przestrzeni społecznej. Chce skończyć z biedą, rozwijając jednocześnie wartości ułatwiające wspólną egzystencje, posiłkując się między innymi twierdzeniem, że istnieje możliwość powstania sprawiedliwego i solidarnego świata. Jednak warunkiem tego jest obalenie rynku. Zwolennicy tego sposobu myślenia konstruowali swoje „autorskie” wizje, których wdrażanie pochłonęło miliony istnień ludzkich, na przykład w przypadku idei socjalizmu. Zwolennicy tego podejścia twierdzą, że: „prawdziwa pozytywna utopia, do której należy pilnie nawiązać, polega na odrodzeniu ideału demokratycznego, zdolnego odrodzić i skanalizować namiętności, które podsycały antykapitalistyczną walkę $w$ dawnych wiekach. Ekonomia i rynek pójdą za tym w ślad" (Caillé, 2007: 38).

- Utopia nowego Kościoła, która może być alternatywą współczesnych systemów religijnych, jak protestantyzm i katolicyzm. Te systemy religijne, według zwolenników wspominanej tutaj utopii, tak dopasowały się do obecnego świata, że przypisuje się im winę za narastające na świecie zło. Nie można oprzeć się spostrzeżeniu, patrząc na Kościoły ostatnich wieków, iż użytkowe eksploatowanie idei przez nie propagowanych wygenerowało „demokracje o niskiej intensywności”. Tutaj zwolennicy podkreślają:

Nowe ruchy ogarniają przede wszystkim ubogie warstwy ludności w krajach Trzeciego Świata i mówią nam wiele o kontekście społecznym, w jakim się rodzą. Nie wyłaniają się jako anachroniczne religijne relikty dawnych czasów, które uparcie nie chcą przeminąć. Wkraczają raczej na opuszczoną przestrzeń, jaka pozostała po klęsce utopii społecznych i politycznych, które przeniosły modernizację i stworzyły obecny porządek polityczny (...). To, czego szukają nawróceni, to nie stopniowa zmiana warunków życia, ale prowizoryczne schronienie, swoista arka Noego, która stawi czoło nadchodzącej katastrofie. (Hurbon, 2007: 40)

- Utopia nieśmiertelnego ciała jest produktem marzenia o wirtualizacji zmysłów, o potrzebie cielesnego odrodzenia i regeneracji ciała. Jest to przekonanie dające nadzieję w sytuacji ograniczoności nauk biomedycznych, które nie mogą skutecznie chronić człowieka przed licznymi epidemiami. Ta utopia postuluje możliwość istnienia odmiennego ciała. Zwolennicy tego kierunku myślowego głoszą:

znajdziemy remedium na wszelkie słabości - zmarszczki, otyłość, łysienie, dysfunkcje seksualne - i wszystkie choroby. To będzie wiek cudów. Kalecy odzyskają utracone członki. Ślepcy odzyskają wzrok. A wszystko to oczywiście dzięki komputerom, które zapewnią dostęp do nowej cyfrowej wersji ciała. (Casilli, 2007: 40) 
- Utopia czystego rozumu wyłania się z chęci uwolnienia świata od ponadnaturalnych iluzji, proponując świat zgodny z rozumem. Ten zbiór poglądów rości sobie pretensje do bycia prawdziwą kulturalną rewolucją społeczeństwa ateistycznego, zarazem wiedząc o tym, że nie jest możliwe istnienie idealnego świata. Jednak, jak twierdzą:

w upowszechnieniu ateizmu przeszkadza także globalny kontekst kulturowy naszej epoki. Chodzi tu zwłaszcza o dwa czynniki: schyłek triumfującego rozumu i przystosowanie się religii do kulturowego relatywizmu. Nie chcemy pytać o prawdę, każdy może mieć swoją.

(Minois, 2007: 42)

W każdej z wyżej wymienionych utopii możemy dostrzec dychotomię, wzajemnie się wykluczające i uzupełniające postawy. Pojawiają się między innymi obok siebie postawy takie jak: $\mathrm{z}$ jednej strony kompetencyjność, $\mathrm{z}$ drugiej działanie zmierzające do tworzenie naukowego getta, $\mathrm{z}$ jednej strony postawa charakteryzująca się umiejętnością dokonywania obserwacji, z drugiej zaś tendencja do tworzenia spiskowych teorii dziejów w przypadku braku racjonalnych argumentów, z jednej strony postawa skłaniająca do dzielenia się oraz akceptacja różnorodności i odmienności, z drugiej tendencja do likwidacji odruchów samoregulacyjnych, $\mathrm{z}$ jednej strony postawa, której towarzyszy odkrywanie „sił duchowych" i krytycyzm, z drugiej - realna sytuacja, w której dominuje poczucie tymczasowości i doraźności rozwiązań. Stąd też, możliwość zaistnienia obok siebie przeciwstawnych postaw tworzy dla każdej z utopii stan bezpieczeństwa jako możliwego i akceptowalnego ryzyka. Dlatego też wydawać się może, że celem każdej z utopii edukacyjnych jest wygenerowanie świadomej postawy, która umożliwi trwanie „pomiędzy”.

\section{Wniosków kilka}

Pytanie o edukację było w dziejach ludzkości zawsze pytaniem o realizację obowiązującej utopii społecznej. I chociaż zarzuca się wszystkim utopizmom, iż posiadają cechę błędnego koła, za każdym razem rozpoczynając wszystko od początku. Albo też formułuje się w stosunku do nich zarzut, że mają tendencję odrywania się od realnego świata. I chociaż dla niektórych, używając słów na przykład Feliksa Konecznego, wybitnego polskiego historyka i historiozofa, twórcy oryginalnej koncepcji cywilizacji, zjawisko utopii można określić mianem „szlachetnego urojenia” lub przejawu ,ignorancji intelektualnej”, to jednak nie można pomyśleć żadnego modelu edukacyjnego, kształtowanego dla potrzeb jakiejkolwiek społeczności, bez elementów myślenia utopijnego. Można zaryzykować twierdzenie, że edukacja jest praktycznym wymiarem realizującej się utopii. Do takich elementów zaliczamy chociażby: 
- działania antycypujące, rozumiane jako tworzenie przestrzeni bezpieczeństwa rozumianego jako efekt kształtowaniu umiejętności, postaw i systemów wartości, sprzyjających budowaniu i ochronie świata;

- jako czasu tworzenia przestrzeni bezpieczeństwa, gdzie uwzględni się świadome i dopuszczalne ryzyko niepowodzenia bądź częściową utratę istotnych elementów „świata życia”;

- i do takiego elementu należy zaliczyć upowszechnianie prawdy o tym, że poznanie i wcześniejsze rozwiązywanie wyzwań jest warunkiem bezpieczeństwa społecznego.

\section{Literatura}

Bacon F. (1955). Novum Organum. Warszawa.

Caillé A. (2007). Utopia antyrynkowa. [W:] G. Minois. Marzenia o których mówi świat. „Forum” nr 17/18, s. 38.

Dróżdż A. (2000). Mity i utopie pedagogiczne. Kraków.

Hurbon L. (2007). Utopia antyrynkowa. [W:] G. Minois. Marzenia o których mówi świat. „Forum” nr $17 / 18$, s. 40.

Jurszo R. (2016). Miasteczko Dziecięce w Podgrodziu. Stalinowska utopia, w której miały rządzić dzieci. http://historia.wp.pl/title,Miasteczko-Dzieciece-w-Podgrodziu-Stalinowska-utopia-w-kto rej-mialy-rzadzic-dzieci,wid,18140308,wiadomosc.html?ticaid=116f75\&_ticrsn=5\#stgOpinie

Kiereś H. (2000). Trzy socjalizmy. Tradycja łacińska wobec modernizmu i postmodernizmu. Lublin.

Kiereś H. (2005). Utopia a edukacja. Tło myślowe sporu o edukację. [W:] P. Jaroszyński (red). Filozofia i edukacja. Lublin.

Koneczny F. (1935; 1996). O wielości cywilizacji. Kraków.

Kwieciński Z. (1998). Dziesięciościan edukacji (składniki i aspekty - potrzeba całościowego ujęcia). [W:] T. Jaworska, R. Leppert (red.). Wprowadzenie do pedagogiki. Wybór tekstów. Kraków.

Mannheim K. (1992). Ideologia i utopia. Lublin.

Mery A. (2007). Utopia wegetariańska. [W:] G. Minois. Marzenia o których mówi świat. „Forum” nr 17/18, s. 37 .

Minois G. (2007). Marzenia o których mówi świat. „Forum” nr 17/18, s. 42.

Naisbitt J., Naisbitt N., Philips D. (2003). High Tech High Touch. Poznań.

Szacki J. (1980). Spotkania $z$ utopia. Warszawa.

Tokarczyk R.A. (1995). Polska myśl utopijna. Trzy eseje z dziejów. Lublin.

Tokarczyk R.A. (2006). Współczesne doktryny polityczne. Kraków. 
